\title{
Monetary Transmission Mechanism in Nigeria: A Causality Test
}

\section{Bernhard Ozofere Ishioro}

\author{
Department of Economics \\ Delta State University, Abraka, Nigeria \\ E-mail:ben_ishioro@yahoo.co.uk
}

Doi:10.5901/mjss.2013.v4n13p377

\begin{abstract}
For decades the major focus of the Central Bank of Nigeria (CBN) has been the formulation and implementation of monetary policies on how to achieve the macroeconomic goals of low inflation, interest rate and exchange rate regulation, and sustained economic growth. But the real sector of the Nigerian economy has performed poorly in terms of sustainable economic growth, low inflation and stable interest and exchange rates. This has resulted in a erratically stable economy; monetary policy-shocks debarred sectors and highly vulnerable macroeconomic aggregates. This study examines the channels of monetary transmission mechanism in Nigeria. The main objective of the study is to identify and validate the existence of some channels of monetary transmission mechanism in the Nigerian context. The study reviewed both the theoretical, empirical and methodological literatures. The Granger causality test was adopted in the estimation of the relationship between the various channels and selected macroeconomic aggregates. Based on the results of our analysis, the study concludes that three channels are functional in Nigeria-the interest rate, exchange rate and the credit channels. We recommend that the exchange rate and interest rate channels should form a fundamental basis for inflation targeting in Nigeria.
\end{abstract}

Keywords: Channels of monetary transmission, Granger causality, macroeconomic aggregates.

\section{Introduction}

The economic literature is replete with the debate concerning the workings of the monetary transmission mechanism as it affects sectors of the economy or key economic variables or as its 'ripples' are distributed in a somewhat wide- spread manner throughout the economy. This means that the issue concerning the impact of monetary policy transmission on the economy in general and on output, prices, investment and other key economic variables in particular has long been a crucial issue of debate.

The seemingly unfathomable issue of whether monetary policy shocks affect real macroeconomic aggregates or not have been acknowledged as a significant gap that remains unfilled with respect to the precise and exact nature of the channels through which monetary impulses are transmitted to either specific sectors or the entire economy. However, it has been observed that the transmission mechanism of monetary policy works through various channels namely exchange rate channel, interest rate channel, bank credit channel and other assets price effect channel (also known as equity price channel) to affect different markets, institutions, sectors at different speeds and intensities (Mihov, 2001; Ganev et al., 2002; Kujis, 2002; Cecchetti, 1999; Elboune et al, 2003; and Juks, 2004).

The identification and evaluation of the above mentioned channels of monetary transmission for any economy especially for the Nigerian economy is very important due to their multi-farious impact and for the following reasons.

First, a clear, sound and functional understanding of the monetary policy transmission mechanism would help the regulatory authorities and other policy makers to interpret with relative precision the movements in both economic and financial variables.

Second, the link of causation between the real sector of the Nigerian economy and the financial sector is very crucial to growth stimulation given that the financial sector of the Nigerian economy is one of the most patronized in the past quinnquennia (Ogunkola and Abubakar, 2008).

Furthermore, appropriate weights and emphasis would be placed and attached to monetary policy targets, instruments and goals when the conduct of monetary policy is designed and implemented, if more and adequate information about the mechanism is gleaned from the analysis made by researchers in general and economists in particular (Adebiyi, 2004).

In Nigeria, the financially repressive policies that preceded the adjustment era of the late 1980s seem to have 
made the understanding of the channels of monetary transmission more difficult due to interest rate stickiness (Rasheed, 2002).

Apart from the seeming impossibility associated with a clear-cut identification of the channels of monetary transmission mechanism the issue of an acceptably appropriate technique of modeling the channels of transmission of monetary policy as identified in the literature is an area of research impasse.

Therefore, the major objective of this paper is to identify and discuss the channels of monetary policy transmission mechanism, and to analyze the modeling techniques adopted by different researchers in the study of the channels of monetary transmission and their impacts on the economy. The rest of the paper is structured as follows: section two focuses on literature review, section three concentrates on the methodology and section four focuses on the analysis of results and section five concludes the paper.

\section{Literature Review}

Anchored on the economic dogma of both the monetarists and the Keynesians; the monetarists argue that the choice of the monetary policy instrument should be set according to the targets of the growth of the money supply and/or monetary aggregates so that the potency of such instruments can best be analyzed by observing these variables.

However, the Keynesians have advanced a strand of argument that the choice of the monetary policy instruments should be set appropriately in order to target the economic variable of policy interest (interest rate). This is why the problem of the identification of the appropriate instrument of monetary policy transmission mechanism has been an agelong controversy.

The volume of literature devoted to the search for the appropriate channel or channels through which monetary policy is transmitted to the economy is unequivocally huge; therefore for convenience of evaluation and effective presentation, the review of related literature is divided into two sub-sections viz: theoretical and empirical review.

\subsection{Theoretical Review}

The monetary transmission mechanism according to Ireland (2005) describes how policy-induced changes in the nominal money stock or the short-term nominal interest rate impact on real variables such as aggregate output and employment. Mishkin (1995) in his work "Symposium on the Monetary Transmission Mechanism" identified four (4) channels of monetary transmission as: interest rate channel, credit channel, exchange rate channel and other Assets Price effects channel. Monetary transmission mechanism due to its complexity and the various erroneous misconceptions associated with it would be better appreciated if the various channels are well elucidated in relation to some key assumptions. We assume in line with Ireland (2005) that:

The liabilities of the Central bank of Nigeria include both components of the monetary base: currency and bank reserves. This explains the fulcrum of the CBN's ability to controls the monetary base. It should be noted that monetary policy actions typically begin when the CBN changes the monetary base through an open market operation, purchasing government bonds in order to increase the monetary base or selling securities to decrease the monetary base. If these policy-induced movements in the monetary base are to have any impact beyond their immediate effects on the central bank's balance sheet, other agents must lack the ability to offset them exactly by changing the quantity or composition of their own liabilities. Therefore, it is safe for any model of the monetary transmission mechanism must assume that there exist no privately-issued securities that substitute perfectly for the components of the monetary base.

The channels of monetary policy transmission mechanism are explained below:

\subsubsection{Interest Rate Channel:}

The interest rate channel of monetary policy transmission has been described by Ogunkola and Abubakar (2008) as the standard Keynesian channel of monetary transmission a la Hicks (1937) which operates within the IS-LM framework and has been replicated by Taylor (1995); Mishkin (1995), Cotarelli and Kourellis (1994); Clarida, Gali and Gertler (2000);and Besimi, Pugh and Adnett (2006).The interest rate channel was clearly defined in Keynes' General Theory (Keynes, 1936; see also Uanguta and Ikhide,2002). Negative monetary shocks limit the banking system's ability to sell deposits. Demand for bonds increases while demand for money decreases. If prices are not fully adjustable, real money balances will decline, pushing up interest rates, and raising the cost of capital. Investment spending declines, reducing both aggregate demand and output. The monetary transmission mechanism under this view works through the liability side of bank 
balance sheets. There are two necessary conditions for the money channel to work. First, banks cannot perfectly shield transaction balances from changes in reserves. Second, there is no close substitute for money in the conduct of transactions in the economy.

Mishkin (1995) observed that the traditional Keynesian view of how monetary tightening is transmitted to the real economy can be represented by a schematic diagram as:

$$
M P \Downarrow \rightarrow I_{R} \Uparrow \rightarrow I N V \Downarrow \rightarrow Y \Downarrow
$$

Where $M P \Downarrow$ indicated a contractionary monetary policy leading to a rise in real interest rate $\left(I_{R} \Uparrow\right)$, which in turn raises the cost of capital; thereby causing a decline in investment spending ( $I N V \Downarrow$ ). This process also lead to a decline in aggregate demand and eventually a fall in output $(Y \Downarrow)$. $\Downarrow$ denotes a decrease or a fall and $\Uparrow$ represents an increase or a rise. In asserting the importance of the interest rate channel in the transmission mechanism, Taylor (1995) argues that financial market prices are key components of how monetary policy affects real activities, in which case a contractionary monetary policy raises short-term interest rates.

Since prices and wages are assumed to be rigid downwards, real long-term interest rates increase as well. These higher real long-term rates lead to a decline in real investment, real consumption, and thereby on real GDP. In the long run, after wages and prices of goods begin to adjust, real GDP returns to normal. In an economy with high inflation, the interest rate channel is incapacitated as it loses strength due to inflationary volatility (Uanguta and Ikhide, 2002).If inflation becomes volatile, its certainty equivalent will exceed its expected value by a volatility premium. Hence, a high real interest rate is not associated with contractionary monetary policy if the volatility premium is also high.Conversely,a lower inflation strengthens the efficiency of the interest rate channel because low inflation means less volatile interest rate.

The interest rate referred to in the above schematic diagram is real interest rate.

This implies that, in real terms, the changes in market interest rates, may affect the costs of financing investments, thereby causing a change in investment spending which affect aggregate demand and hence output.

\subsubsection{The Credit Channel:}

The credit channel consists of a set of factors that amplify and propagate the conventional interest rate effects. This implies that, the credit channel is an enhancement mechanism, not a truly independent or parallel channel.The presence of asymmetric information and costly enforcement of contract have informed the emergence of two channels of monetary transmission mechanism within the credit channel viz: the Bank lending (the narrow credit) and the Balance Sheet channels (Uanguta and Ikhide, 2002).

The bank lending channel is pivoted on the theoretical assumption that banks play a special role in the financial system because they issue bank deposits that contribute to the broad monetary aggregates and also by holding assets and bank loans that are suitable for different types of borrowers. According to Mishkin (1995), contractionary monetary policy that decreases bank reserves and bank deposits exert impact through its effect on these borrowers. The CBN can regulate the availability of banks loans in two main an ways: First,the CBN can raise reserves requirements with the ultimate intention of reducing both the total volume of commercial bank assets and the proportion of commercial banks earning assets to total assets.Second,the CBN can conduct open market sales of treasury bills and government development stock. This is aimed at reducing commercial banks' reserves-as depositors will substitute commercial banks deposits with more attractive alternative financial assets. This channel can be represented schematically as:

$$
\begin{aligned}
& M P \Downarrow \rightarrow B D \Downarrow \rightarrow B C L \Downarrow \rightarrow I N V \Downarrow \rightarrow Y \Downarrow \\
& \text { Where } M P \Downarrow \text { denotes contractionary monetary policy } \\
& B D \Downarrow \text { denotes decrease in bank deposits } \\
& B C L \Downarrow \text { denotes decrease in bank loans } \\
& I N V \Downarrow \text { denotes decrease in investment } \\
& Y \Downarrow \text { denotes decrease in output, and } \\
& \Downarrow \text { denote a decrease or a fall. }
\end{aligned}
$$

Based on this microcosm, a contractionary monetary policy lowers the network of firms and so leads to lower investment spending and aggregate demand because of the increase in adverse selection and moral hazard.

The balance sheet channel is based on the theoretical prediction that the external finance premium facing a borrower should depend on borrower's financial position. The balance sheet channel of monetary policy arises because 
the shifts in policy affect not only market interest rates but also the financial positions of borrowers, both directly and indirectly. A tight monetary policy directly weakens borrowers' balance sheets in at least two ways. First, rising interest rates directly increase interest expenses, reducing net cash flows and weakening the borrower's financial position. Second, rising interest rates are also typically associated with declining asset prices, which among other things shrink the value of the borrower's collateral. Indirect effect of tight monetary policy on net cash flows and collateral values is from deterioration in consumers' expenditure. The firm's revenues will decline while its various fixed or quasi-fixed costs do not adjust in the short run. The financing gap, therefore, erodes the firm's net worth and credit worthiness over time. The balance sheet channel operates through the network of business firms (Bernanke and Blinder 1988, 1992). A drastic reduction in the network of business firms raises the adverse selection and eventually leads to a decrease in the tempo of lending to finance investment spending (Romer and Romer, 1990).

\subsubsection{Exchange Rate Channel}

This channel of monetary transmission mechanism focuses on the link between net private capital inflows and monetary policy after financial reforms leading to liberalization. According to Taylor (1995) and Obstfeld and Rogoff (1995), the exchange rate channel works through the aggregate demand as well as the aggregate supply effects which is more effective under the flexible exchange rate regime. This channel of monetary policy involves interest rate effects. Mishkin (1995) presented the schematic diagram for the monetary transmission mechanism operating through the exchange rate channel as:

$$
M P \Downarrow \rightarrow I_{R} \Uparrow \rightarrow E R \Uparrow \rightarrow N X \Downarrow \rightarrow Y \Downarrow
$$

Where $\Downarrow(\Uparrow)$ denote a decrease(an increase) or a fall( a rise).

$M P \Downarrow$ denotes contractionary monetary policy,

$I_{R} \Uparrow$ denotes increase in interest rate (real),

$E R \Uparrow$ denotes increase in exchange rate,

$N X \Downarrow$ denotes decrease in net export and

$Y \Downarrow_{\text {denotes a fall in output. }}$

When domestic real interest rates rise $\left({ }_{R} \Uparrow\right)$, domestic deposits become more attractive relative to deposits denominated in foreign currencies, thus leading to a rise in the value of the domestic currency relative to other currencies and deposits this gives rise to an increase in exchange rate( $E R \Uparrow)$, thereby causing a fall in both net exports ( $N X \Downarrow$ ) and output $(Y \Downarrow)$.

\subsubsection{Other Assets Price Effect (Equity Price Channel)}

Two sub-channels are involved in the equity price channel that are important to the monetary transmission mechanism. These include the Tobin $q$ theory of investment and wealth effects on consumption. These two sub-channels are based on the monetarists' paradigm.

The Tobin $q$ theory $a^{\prime} l a^{\prime}$ Tobin (1969) defines $q$ as the market value of firms divided by the replacement cost of capital. The theory provides a mechanism through which monetary policy affects the economy through its effects on the valuation of equities. This is represented schematically as:

$$
\begin{aligned}
& M \Downarrow \rightarrow P e \Downarrow \rightarrow q \Downarrow \rightarrow I \Downarrow \rightarrow Y \Downarrow \\
& \text { where } \Downarrow \text { (介) denotes decrease (increase). } \\
& \mathrm{M} \Downarrow \text { denotes contractionary monetary policy } \\
& \mathrm{Pe} \Downarrow \text { denotes decrease in prices of equity } \\
& \mathrm{q} \Downarrow \text { denotes divided by the replacement cost of capital. } \\
& \mathrm{I} \Downarrow \text { denotes a fall in investment and } \\
& \mathrm{Y} \Downarrow \text { denotes a decrease in output. }
\end{aligned}
$$


The rise in interest rates as a result of the contractionary monetary policy makes bonds more attractive relative to equities, thereby causing the price of equities to fall. The major intuition drawn from the above analysis is that, lower equity prices (Pe $\Downarrow$ ) will lead to a lower $\mathrm{q}(\mathrm{q} \Downarrow)$ and therefore a lower investment spending $(\downarrow \Downarrow)$ culminating into one of the sub-channels of the other assets prices channel of monetary transmission mechanism.

The other sub-channel found in the channel of monetary transmission through other assets prices channel is the wealth effect on consumption. The wealth channel was modeled on the life-cycle hypothesis of consumption developed by Modigliani (1971), in which households' wealth is a principal determinant of consumption spending. A major component of financial wealth is common stocks. The link to monetary policy emanates from the relationship between interest rates and asset prices (especially common stocks). When stock prices fall, the value of financial wealth decreases, thereby decreasing the lifetime resources of consumers, hence consumption is expected to fall (Ahmad et al., 2008).

Therefore, a contractionary monetary policy will lead to a decline in stock prices (Pe $\Downarrow$ ) resulting into another subchannel of transmission mechanism in the other assets prices channel. This can be presented schematically as:-

$\mathrm{M} \Downarrow \rightarrow \mathrm{Pe} \Downarrow \rightarrow$ wealth $\Downarrow \rightarrow$ consumption $\Downarrow \rightarrow \mathrm{Y} \Downarrow$

$\Downarrow(\Uparrow)$ denotes a decrease ( an increase).

$\rightarrow$ denotes the transmission effect.

$\mathrm{M} \Downarrow$ denotes contractionary monetary policy

Pe $\Downarrow$ denotes equity prices

Where $\Downarrow$ denotes decrease in financial wealth $\Downarrow$ leading to a fall in consumption (consumption $\Downarrow$ ) and $Y \Downarrow$ denotes decrease in output.

But an increase in consumption increases aggregate demand and output, and hence results into an increase in the general price level.

\subsubsection{Recent Developments in Monetary Transmission Mechanism.}

Recent studies on the monetary transmission mechanism seek to understand how the traditional Keynesian interest rate channel operates within the context of dynamic, stochastic, and general equilibrium models. These are advancements and developments on early attempts by Fischer (1977) and; Phelps and Taylor (1977) to combine the key assumption of nominal price or wage rigidity with the assumption that all economic agents have rational expectations that enable them to overturn the policy ineffectiveness result that McCallum (1979) after the pragmatic practice of Lucas (1972) and; Sargent and Wallace (1975). These studies built on those earlier studies by deriving the key behavioural equations of the New Keynesian model from more detailed descriptions of the objectives and constraints faced by optimizing households and firms (see Ireland, 2005 for details).

\subsection{Methodological Review}

For several decades, the empirical investigation of the channels through which the effects of monetary policy are transmitted to the real sector was conducted based on the IS-LM model. However, the widespread dissatisfaction with the theoretical incompatibility of the IS-LM model with empirical results led to the search for a more appropriate theoretical framework and modeling technique.

However, given the lack of consensus about the workings of the monetary policy transmission mechanism, several methodological techniques have been adopted in the literature to estimate the effect of monetary policy on domestic price, output, domestic credit, wages, money and exchange rate using different monetary policy instruments (Rasheed, 2002).

Some of the modeling techniques adopted includes the Ordinary Least Square (OLS) in the evaluation and estimation of the transmission mechanism model. Despite the innumerable advantages associated with the OLS as regards the 'BLUE' property and the simplicity thereof, it has failed to capture the effect of monetary policy on the real sector in particular and the economy in general. Beyond that, Gujarati (2004) has criticized the sole application of the OLS to the estimation of econometric models as it can only establish a linear relationship. The models in this category include Fanelli and Paruolo (1999), Garcia et al., (2003) and Allen and Robinson (2004).

Other studies adopted the Vector Autoregressive (VAR) model and structural VAR model in their estimation. Sims 
(1992) estimated separate VARs for Germany, France, the United Kingdom and the United States using monthly data. The study included the following variables in the model: industrial production, consumer prices, and short term interest rate as measure of monetary policy, a measure of money supply, an exchange rate index and an index of commodity prices. According to Sims (1992), output has a hump shaped response to monetary policy shocks. He observed that the interest rates variables potentially affected other variables contemporaneously while the interest rate variable is not affected by innovations in any of the other variables. The results were similar for all the countries studied.

Bernarke and Blinder (1992) studied the credit channel of the U.S, using the federal funds rate, unemployment rate, logarithm of Consumer Price Index (CPI), deposits, loans and securities. The identifying assumption was similar to that of Sims (1992) - monetary policy is predetermined. They found that both the conventional money demand and the credit mechanisms operate; and after two years, the entire long run impact of the decline in deposits is reflected in loans. Therefore, they concluded that their finding support the operation of a credit channel.

However, Rossiler (1995); Miron, Raner and Weil (1995) suggest that the interest rate spreads are alternative focuses on monetary aggregates under the credit channel because not all financial assets are perfect substitutes (Claassen, 1997) and not all economic agents are identical. Christiano et al (1994) adopted the United State quarterly data to test the effect of monetary policy shocks. They adopted similar identifying assumptions as Sims (1992) and explicitly included commodity prices to avoid the price puzzle. The variables used include real GDP, the GDP deflator, commodity price, federal fund rate, non borrowed reserves, total reserves and net funds raised through financial markets, their results confirmed that the initial effects of a positive shock to the federal funds rate is to increase net funds raised by the business firms for almost a year and it declined thereafter.

Dale and Halden (1995); and Carpenter (1996) extended Bernanke and Blinder (1992) study. But they used similar estimation methods; they examined a small sectoral (household and corporate) VAR model of the United Kingdom economy. Their results indicated that there is a significant sectoral difference among the channels of monetary transmission. Their results were consistent with Gartler and Gilchrist (1993).

Another approach adopted for the study of the credit channel was provided by Kashap, Stein, and Wilcox (1993). They establish a simple model that explains that two necessary conditions must be satisfied if monetary policy is to impact on aggregate demand through a distinct lending channel. The condition include:

First, loans and commercial papers must be imperfect substitutes to bank assets. Hence, banks cannot just reduce commercial papers in order to keep the supply of loans unchanged. Second, loans and commercial paper must be imperfect substitutes to corporate liabilities. Their empirical evidence concludes that both conditions were satisfied. A corollary to the above conditions is that there must be imperfect price adjustments in order to allow the monetary policy to affect real activity.

Anti-Ego (2006) studied alternative domestic monetary policy strategies in Uganda. The study used base money growth changes in the treasury bill rate, inflation, and output growth to estimate a VAR with two alternate orderings, one reflecting a reactive and another a proactive monetary policy stance. The study covered a period of 1982 to 1997 . Using Granger Causality tests, the found that the Treasury bill rate has not been important for movement in prices. His results concluded that inflation mainly explained its own movements in the first five quarters after which base money becomes important explaining about $30 \%$ of the variations in the reactive ordering and about $40 \%$ of the variations using the proactive orderings.

\subsection{Empirical Review}

Some studies such as Gertler and Gilchrist (1993, 1994), Christiano, Eichenbaum and Evans (1996); and Domac (1999) study the effects of a contractionary monetary policy on both large and small manufacturing firms. Gertler and Gilchrist $(1993,1994)$ find that the effect of cash flow squeeze on economic behavior depend largely on firms' ability to smooth the decrease in cash flows by borrowing. The large firms can be at least temporally able to maintain their levels of production and employment in the face of higher interest costs and declining revenues through other sources of short-term credit. The inventories of large firms are expected to grow following a contractionary monetary policy. But, the small firms, who have more limited access to short-term credit markets, tend to de-accumulate inventories by cutting work-hours and production alike.Similarly, Domac (1999) obtains similar results for the study on Malaysia. Christiano, Eichenbaum and Evans (1996) study how the flow of funds between different sectors response to a monetary shock (see also Ahmad,2008;Altunbas et al.,2002; Arena et al,.2006 ) The results indicate that business and household sector do not adjust their financial assets and liabilities similarly after a monetary shock.

But in Nigeria, a lot of studies( such as Uchendu (1996); Ikhide (1996); and Ikhide and Alawode (1994, 2001); 
Ayodele (1990); Rasheed (2002) and Omotor (2007)) have been conducted on different aspects of monetary transmission mechanism.

\section{Data and Methodology}

\subsection{Source and Description of Data}

In order to ascertain the relationship in terms of the causal linkage between the variables that represent the transmission channels and the economy, different transmission variables were used as documented in the literature. Transmission mechanism indicators include interest rate, exchange rate and private domestic credit extended by the banking system. Real Per capita Gross Domestic Product is used as a proxy for economic growth. The description of the other variables used in this study is presented in the table below:

Table 1: Description of Variables

\begin{tabular}{|c|l|l|c|}
\hline S/No & \multicolumn{1}{|c|}{ Variables } & \multicolumn{1}{|c|}{ Data Source } & Symbol \\
\hline 1 & Interest Rate & Central Bank of Nigeria (CBN) Statistical Bulletin & InR \\
\hline 2 & Investment & Central Bank of Nigeria (CBN) Statistical Bulletin & InvT \\
\hline 3 & Per Capital GDP & Central Bank of Nigeria (CBN) Statistical Bulletin & PCGDP \\
\hline 4. & Exchange Rate & Central Bank of Nigeria (CBN) Statistical Bulletin & REXH \\
\hline 5. & Prices & Central Bank of Nigeria (CBN) Statistical Bulletin & PR \\
\hline 6. & $\begin{array}{l}\text { Private domestic credit extended } \\
\text { by the banking system }\end{array}$ & Central Bank of Nigeria (CBN) Statistical Bulletin & PDCR \\
\hline
\end{tabular}

Source: Author's Compilation

The study used annual time series data from 1970 to 2011. As shown in table 1 above, data for the variables employed in the determination of the stationarity of data using the Augmented Dickey Fuller (ADF) and the estimation of the Granger Causality test were sourced from the Central Bank of Nigeria (CBN) Statistical Bulletin (for various years).

\subsection{Estimation Techniques}

\subsubsection{The Augmented Dickey Fuller Unit Root Test}

Following the pragmatic practice of recent studies on the test for stationarity and unit root, the ADF equations are specified as shown below:

$$
\begin{aligned}
& \Delta V_{i}=\eta V_{i-1}+\eta \sum_{i=1}^{n} \Delta V_{i-j}+e_{t} \\
& \Delta V_{i}=\sigma_{0}+\varphi V_{i-1}+\eta \sum_{i=1}^{n} \Delta V_{i-j}+e_{t} \\
& \Delta V_{i}=\sigma_{0}+\sigma_{1} i+\eta V_{i-1}+\eta \sum_{i=1}^{n} \Delta V_{i-j}+e_{t}
\end{aligned}
$$

In equation (1) and (2) above, $V_{i}=(\operatorname{InR}, \operatorname{InvT}, P C G D P, R E X H, P R, P D C R)$ representing the variables used for the unit root test. Usually, the unit root test is conducted on individual variables using either intercept without trend or intercept with trend. Hence, equation (1) represents the model without intercept and no trend; equation (2) represents the model with intercept but no trend while equation (3) represents the model with intercept and trend. One of the standard conditions required for the implementation of the ADF unit root test is that both the null and alternative hypotheses must be stated and tested. Therefore, we state the hypothesis as follows:

$\mathrm{H}_{0}: \eta=1$. This connotes the presence of a unit root using either equation (1), (2) or (3).

$\mathrm{H}_{\mathrm{A}}:|\eta| \angle 1$. This connotes the absence of unit root using either of equation (1), (2) or (3). 
The rejection (non-rejection) of the null hypothesis is the non-rejection (rejection) of the alternative hypothesis.

\subsubsection{The Granger Causality Test}

Given that the Pair-wise Granger Causality test is usually adopted as a test of the evidence of a causal relationship among variables, we have decided to conduct a Pair-wise Granger Causality test on the variables presented in table 1 above.

This is to enable us establish the existence of and direction of causality. A prominent reason for this is that the tests provide preliminary evidence on the interrelationship among variables that studies both the structural specification of the VAR model and the form of its identifying restrictions. Therefore, the adoption of the Granger Causality test is a structural issue that gives us the directional causation of the variables that constitute the monetary transmission mechanism.

Furthermore, we have adopted the Granger causality test because although regression analysis deals with the dependence of one variable on the other variables, it does not necessarily imply causation i.e. the existence of a relationship between variables does not prove causality or the direction of influence. But the Granger Causality test assumes that the information relevant to the prediction of the respective variables is contained solely in the time series data on these variables; where it is assumed that the disturbances $\varnothing_{1 \mathrm{t}}$ and $\varnothing_{2 \mathrm{t}}$ are uncorrelated (we are dealing with bilateral causality).

Also, we decide to use the Granger Causality tests based on pragmatic grounds after Anti-Ego (2000) but with somewhat different variables since some of the variables adopted by Anti-Ego (2000) as cited in Ogunkola and Abubakar (2008) like the Treasury bill rate were not significant in his tests. To test the causal relationships, the following unrestricted model is used.

$$
\begin{gathered}
y_{t}=\sum_{j=1}^{k} \alpha_{i} y_{t-1}+\sum_{i=1}^{k} \beta_{i} x_{t-1}+u_{i t} \\
x_{t}=\sum_{j=1}^{k} \alpha_{i} x_{t-1}+\sum_{i=1}^{k} \beta_{i} y_{t-1}+u_{2 t}
\end{gathered}
$$

Where $u_{1 t}$ and $u_{2 t}$ are two white noise series and $k$ is maximum number of lags. Granger causality is very sensitive with the number of lags used. Four findings are possible in Granger causality test.

a) Neither variable 'Granger Causes' the other

b) Uni-directional causality from $x$ to $y$ but not vice versa

c) Uni-directional causality from $y$ to $x$ but not vice versa

d) Both variables cause each other (bi-directional causality).

\section{Discussion of Results}

\subsection{Results of the Augmented Dickey Fuller Unit Root Test.}

\begin{tabular}{|c|c|c|c|c|c|c|c|}
\hline \multirow[b]{2}{*}{ Variable } & \multicolumn{2}{|c|}{ ADF Statistics } & \multicolumn{2}{|c|}{ Mackinnon Critical Values at 5 percent } & \multirow[b]{2}{*}{$\begin{array}{l}\text { Order of } \\
\text { Integration }\end{array}$} & \multirow[b]{2}{*}{$\begin{array}{c}\text { Number of } \\
\text { Lags }\end{array}$} & \multirow[b]{2}{*}{$\begin{array}{l}\text { ADF Test Equation } \\
\text { include }\end{array}$} \\
\hline & Level & $\begin{array}{c}\text { First } \\
\text { Difference }\end{array}$ & Level & $\begin{array}{c}\text { First } \\
\text { Difference }\end{array}$ & & & \\
\hline $\ln R$ & -2.906 & -6.150 & -3.545 & -3.551 & $\mathrm{I}(1)$ & 2 & Intercept and trend \\
\hline $\operatorname{InvT}$ & -1.453 & -4.847 & -2.972 & -4.335 & $\mathrm{I}(1)$ & 2 & Intercept and trend \\
\hline PCGDP & -0.921 & -4.203 & -3.545 & -3.551 & $\mathrm{I}(1)$ & 2 & Intercept only \\
\hline REXH & -0.109 & -5.713 & -3.545 & -3.551 & $\mathrm{I}(1)$ & 2 & Intercept and trend \\
\hline PR & -2.544 & -7.120 & -3.712 & -4.360 & $\mathrm{I}(1)$ & 2 & Intercept only \\
\hline PDCR & -1.642 & -5.264 & -3.699 & -4.339 & $\mathrm{I}(1)$ & 2 & Intercept only \\
\hline
\end{tabular}

Table 2: Result of ADF Unit Root Tests

Source: Author's computation

The results of the ADF unit root test presented above shows that all the variables employed in this are not stationary at 
levels, which implies that they are not integrated of order one. However, the variables were stationary at first difference, that is, they are integrated of order one.Therefore,we do not reject the null hypothesis of the presence of a unit root in each of our variables at levels This satisfies one of the conditions for the implementation of the Granger causality test namely, the variables must be integrated of the same order (stationary at the same level).We carefully selected our lags given that the appropriateness of the selected lag(s) determine the direction of causality. Hence, the number of lags is also reported. Thus, we proceed to test for the Granger causality.

\subsection{Results of the Granger Causality test.}

The results obtained are summarized in table 3 below.

Table 3: Result of Pair-wise Granger Causality Tests.

\begin{tabular}{|c|c|c|c|}
\hline Null Hypothesis & F-Statistics & Direction of Causality & Decision \\
\hline $\begin{array}{l}\text { REXH does not Granger cause PDCR } \\
\text { PDCR does not Granger cause REXH }\end{array}$ & $\begin{array}{l}4.36^{* \star} \\
2.81^{\star * \star}\end{array}$ & $\begin{array}{l}\text { REXH } \Rightarrow \text { PDCR } \\
\text { PDCR } \Rightarrow \text { REXH }\end{array}$ & $\begin{array}{l}\text { Reject Null Hypothesis } \\
\text { Reject Null Hypothesis }\end{array}$ \\
\hline $\begin{array}{l}\text { REXH does not Granger cause PCGDP } \\
\text { PCGDP does not Granger cause REXH }\end{array}$ & $\begin{array}{l}1.78 \\
1.73\end{array}$ & - & $\begin{array}{l}\text { Do not Reject } \\
\text { Do not Reject }\end{array}$ \\
\hline $\begin{array}{l}\text { REXH does not Granger cause PR } \\
\text { PR does not Granger cause REXH }\end{array}$ & $\begin{array}{l}13.38^{\star} \\
46.37^{*}\end{array}$ & $\begin{array}{l}\text { REXH } \Rightarrow \mathrm{PR} \\
\mathrm{PR} \Rightarrow \mathrm{REXH}\end{array}$ & $\begin{array}{l}\text { Reject } \\
\text { Reject }\end{array}$ \\
\hline $\begin{array}{l}\text { REXH does not Granger cause InR } \\
\text { InR does not Granger cause REXH }\end{array}$ & $\begin{array}{l}0.37 \\
4.02^{* *}\end{array}$ & $\operatorname{InR} \Rightarrow$ REXH & $\begin{array}{l}\text { Do not Reject } \\
\text { Reject }\end{array}$ \\
\hline $\begin{array}{l}\text { InR does not Granger cause PDCR } \\
\text { PDCR does not Granger cause InR }\end{array}$ & $\begin{array}{c}29.21^{*} \\
0.083\end{array}$ & $\operatorname{InR} \Rightarrow$ REXH & $\begin{array}{c}\text { Reject } \\
\text { Do not Reject }\end{array}$ \\
\hline $\begin{array}{l}\text { PCGDP does not Granger cause PDCR } \\
\text { PDCR does not Granger cause PCGDP }\end{array}$ & $\begin{array}{l}0.36 \\
1.08\end{array}$ & - & $\begin{array}{l}\text { Do not Reject } \\
\text { Do not Reject }\end{array}$ \\
\hline $\begin{array}{l}\text { PR does not Granger cause InR } \\
\text { InR does not Granger cause PR }\end{array}$ & $\begin{array}{l}0.29 \\
0.20\end{array}$ & $\begin{array}{l}- \\
-\end{array}$ & $\begin{array}{l}\text { Do not Reject } \\
\text { Do not Reject }\end{array}$ \\
\hline $\begin{array}{l}\text { PCGDP does not Granger cause InR } \\
\text { InR does not Granger cause PCGDP }\end{array}$ & $\begin{array}{l}1.72 \\
0.29\end{array}$ & - & $\begin{array}{l}\text { Do not Reject } \\
\text { Do not Reject }\end{array}$ \\
\hline $\begin{array}{l}\text { InvT does not Granger cause InR } \\
\text { InR does not Granger cause InvT }\end{array}$ & $\begin{array}{c}1.27 \\
3.46^{\star *}\end{array}$ & $\stackrel{-}{\operatorname{lnR}} \Rightarrow \operatorname{InvT}$ & $\begin{array}{l}\text { Do not Reject } \\
\text { Reject }\end{array}$ \\
\hline
\end{tabular}

* denotes significance at $1 \%$ level, ${ }^{* \star}$ denotes significance at $5 \%$ level, and, ${ }^{* \star}$ denotes significance at 10\% level.

Source: Author's Computation using Eviews 4.

Our results indicate or suggest that there is no causal linkage between REXH and PCGDP; PCGDP and PDCR; PR and InR; and PCGDP and InR. Therefore, we do not reject the null hypothesis in respect of the above variables causing each other.

However, there is a uni-directional causality from InR to REXH without a reverse causality; also these is a unidirectional causality from InR to PDCR; and from InR to INVT. This implies that interest rate Granger causes exchange rate but exchange rate does not Granger cause interest rate; also interest rate Granger causes private domestic credit extended by the banking system but private domestic credit does not Granger cause interest rate; and finally, interest rate Granger causes investment but investment does not Granger cause interest rate.

Furthermore, our results suggest that these are a bi-directional causality between PDCR and REXH, and REXH and PR. This means that both REXH and PDCR Granger cause each other and, REXH and PR Granger cause each other.

These results have serious implications for the impact of monetary policy transmission mechanism in Nigeria. By this we mean that the interest rate channel of monetary policy transmission exerts serious impact on the exchange rate channel, investment and credit channel in Nigeria.

Our results when viewed in the benchmark of the New Keynesian model, seem to suggest that monetary policy operate effectively through the traditional Keynesian interest rate channel which implies that a monetary tightening in the form of a shock to the Taylor rule that increases the short-term nominal interest rate would translate into an increase in the real interest rate as well when nominal prices move sluggishly due to costly or staggered price setting. This can be 
explained in the light that the rise is the real interest rate might cause households to cut back on their spending as summarized by the IS curve and business firms also cut back on their investment due to the rise in the cost of capital. Also operating through the Phillips curve, the decline in output puts a downward pressure on inflation, which adjusts only gradually after the shock.

Besides, our results seem to suggest that both the exchange rate and price channels, and the exchange rate and credit channels exert decisive pressure on each other. The results suggest that exchange rate channel is active in Nigeria; this finding is not surprising because Nigeria share a relatively great volume of exports and imports with the rest of the world. The importance of the exchange rate channel in Nigeria justifies the monetary policy strategy followed by the $\mathrm{CBN}$ in terms of exchange rate target regime over the years. Also, our result suggest that the exchange and interest rate channels being the most active channels in Nigeria should be used as the two leading indicators for inflation targeting.

Indeed, the interest rate channel seems to be the most important one in terms of debit. This is because the propagations of the monetary policy impulses pass through the broad money to impact either directly or indirectly via the prices, the real activity. Our findings are in line with the CBN (2010) results.

\section{Conclusion and Recommendations}

From our results, it can be concluded that the interest rate channel and the exchange rate channels are the most functionally important channels of monetary policy transmission in Nigeria as these were linked unidirectional to other channels; and the macroeconomic variables in these channels were very significant in our analysis. Hence, we conclude in line with Omotor (2007) that monetary policy fundamentally aimed at achieving stable prices is essential for the purpose of economic growth.

Therefore, for the efficiency and effectiveness of monetary policy, the variables that are implicitly or explicitly related to the interest rate and exchange rate channels should be targeted in order to stimulate sectoral structural reorientation and economic growth.

In order to strengthen the effectiveness of the monetary targeting strategy the CBN should ensure that any new Department charged with the responsibility of empirically studying the specification as well as the ensuring of the stability of money demand functions should be created out of the current department for economists and statistics.

\section{References}

Adebiyi, M. A. (2004), Stability of Money Demand and Monetary Policy in Nigeria: An Error Correction Analysis Model. The Journal of Social and Management Sciences, 1(1): 53-70.

Ahmad, S. (2008). Monetary transmission mechanism in Fiji and PNG. International Research Journal of Finance and Economics, Vol. 15, 284-290.

Allen, C. and W. Robinson (2004): Monetary Policy Rules and the Transmission Mechanism in Jamaica. Bank of Jamaica working paper.

Altunbaş, Y., Fazylov, O., \& Molyneux, P. (2002). Evidence on the bank lending channel in Europe. Journal of Banking \& Finance, Vol. 26, 2093-2110.

Anti-Ego (2000):Setting Monetary Policy instruments in Uganda,In:Mahadeva, L and G.Sterne(eds).MonetaryPolicy Framework in a Global Context.

Arena, M., Reinhart, C., \& Vázquez, F. (2006). The lending channel in emerging economies: Are foreign banks different? Working Paper No. 12340, National Bureau of Economic Research, Cambridge: MA.

Ayodele, J. (1990): The Demand for Money and the Channels of Monetary Shocks Transmission in Nigeria. The Nigerian Journal of Economic and Social Studies (NJESS) Vol. 32: No. $12,3$.

Bernanke, B.S. and A.S. Blinder (1988): Credit, Money, and Aggregate Demand. American Economic Review 78, 435-439.

Bernanke, B. S. and A.S. Blinder (1992): The Federal Fund Rate and the Channels of Monetary Transmission, American Economic Review, 8, 2/4 : 901-921.

Carpenter, S. B. (1996). Informal Credit Markets and the Transmission of Monetary Policy: Evidence, from South Korea, Princeton University working paper, November.

Central Bank of Nigeria [CBN](2010):Monetary Policy Transmission Mechanism in Nigeria, A collection of studies on Monetary Policy Transmission Mechanism in Nigeria.

Central Bank of Nigeria [CBN] (2010): Statistical Bulletin (Official Data Manual of the Central Bank of Nigeria).

Central Bank of Nigeria [CBN] (2012): Statistical Bulletin (Official Data Manual of the Central Bank of Nigeria).

Cecchetti, S.G. (1999): Legal Structure, Financial Structure and the Monetary Policy Transmission Mechanism. National Bureau of Economic Research, Working Paper, No.7151. 
Christiano, L. J.; M. Eichenbaum, and C. Evans (1994): Identification and Effects of Monetary Policy Shocks, Federal Reserve Bank of Chicago working paper (94-7).

Claassen, E. (1997): Global Monetary Economics. Oxford University Press. New York.

Clarida, R.; J. Gali and Gertler M. (2000): Monetary Policy Rules and Macroeconomic Stability:Evidence and some theory. Quarterly Journal of Economics IIJ (147-80).

Cottarelli, C. and A. I.Corelis (1994): Financial Structure, Bank Lending Rates and Transmission Mechanism of Monetary Policy. IMF Staff Papers 587-628.

Dale, S. and Haldane, A. G. (1995) Interest Rates and the Channels of Monetary Transmission: Some Sectoral Estimates. European Economic Review, 39: 1611-1626.

Domaç, I. (1999): The distributional consequences of monetary policy: Evidence from Malaysia. World Bank Policy Working Paper No. 2170, World Bank.

Elbourne, A., de Haan, J., Kiviet, \& M.C., Bas (2003): Financial Structure and Monetary Policy Transmission in Transition Countries. Mimeo, University of Groningen.

Fanelli, L. and P. Paruolo, (1999). New Evidence on the Transmission Mechanisms of Monetary Policy in Italy before stage III of European Monetary Union, Ricerche Quantitative per la politica Economica.

Fischer, S. (1977):Long-Term Contracts, Rational Expectations, and the Optimal Money Supply Rule. Journal of Political Economy 85, 191-205.

Garcia, C. Garcia P. Magendzo, L. and J. Restrepo (2003): The Monetary Transmission Mechanism in Chile: A Medium sized Macro econometric Model. Central Bank of Chile working paper wp 254.

Ganev, G., Molnar, K., Rubinski K., \& P., Wozniak (2002): Transmission Mechanism of Monetary Policy in Central and Eastern Europe. Centre for Social and Economic Research, Warsaw, Case Reports, No.52.

Gertler, M. \& S. Gilchrist (1993): The Role of Credit Market Imperfections in the MonetaryTransmission Mechanism: Arguments and Evidence. Scandinavian Journal of Economics. 95/1: 43-64.

Gertler, M. \& S. Gilchrist (1994): Monetary Policy, Business Cycles, and the Behavior of Small Manufacturing Firms. Quarterly Journal of Economics: $309-340$.

Gujarati, D. N. (1995) Basic Econometrics McGraw- Hill, Inc. 3rd Edition.

Ikhide, S. J. (1996). Financial Sector Reforms and Monetary Policy in Nigeria. Institutes of Development Studies, working papers 68.

Ikhide, S. I. and A. A. Alawode (1994): Financial Sector Reforms, Macroeconomic Instability and the Order of Economic Liberalization. The Evidence from Nigeria. AERC Final Report.

Ikhide, S. I. and. A. A. Alawode (2001): Financial Sector Reforms, Macroeconomic Instability and the Order of Economic Liberalization. The Evidence from Nigeria, AERC, Nairobi, Kenya, Research paper 112: 1- 41.

Juks, R.( 2004):Monetary policy transmission mechanisms: a theoretical and empirical overview. In: The Monetary Transmission Mechanism in the Baltic States, Tallinn). Available at: http://eestipank.info/pub/en/dokumendid/publikatsioonid/seeriad /muud_uuring ud/2004/_2.pdf?objld=533623

Kashyap, A. K.; Stein, J. C. \& D. W. Wilcox (1993): Monetary Policy Instruments in Uganda. In Monetary Policy Frameworks in Global Context edited by L. Mahadeva and G. Steme.

Keynes, J.M. (1936): The General Theory of employment, Interest and Money, Macmillan and co., Ltd., London.

Kujis, L. (2002): Monetary Policy Transmission Mechanism and Inflation in the Slovak Republic. IMF Working Paper, No. 02/80.

Lucas R.E. (1972): Expectations and the Neutrality of Money. Journal of Economic Theory 4,103-124.

Mihov, I. (2001): Monetary Policy Implementation and Transmission in the European Monetary Union. Economic Policy 31, $371-406$.

Miron, J. A.; Romer C. D. \& D. N. Weil (1995): Historical Perspectives on the Monetary Transmission Mechanism. National Bureau of Economic Research working paper No. 4326.

Mishkin, F. S. (1995): "Symposium on the Monetary Transmission Mechanism" Journal of Economic Perspective, 9, 3 -10.

Modigliani, F. (1971). Monetary Policy and Consumption. In Consumer spending and Monetary Policy: the Linkages, Boston, Federal Reserve Bank of Boston, 9- 84

Obstfeld, M. and Rogoff, K. (1995). Exchange Rates Dynamics Redux. Journal of Political Economy 103, 624-660.

Ogunkola, E. and T. Abubakar (2008): Monetary Policy Transmission Mechanism in Sierra Leone: A Vector Error Correction (VEC) Approach: A paper presented at CEAR, Ibadan.

Omotor, D.G.(2007): Monetary Policy and Economic Development: Conceptual and Theoretical Issues,CBN,Economic and Financial Review 45(39-63).

Phelps, E.S. and J.B.Taylor (1977): Stabilizing Powers of Monetary Policy under Rational Expectations. Journal of Political Economy 85 163-190.

Romer, C. and D. Romer (1990): New Evidence on the Monetary Transmission Mechanism. Brookings Papers on Economic Activity 1: 149- 198.

Rossiler, R. D. (1995): Monetary Policy Indicators after Deregulation. The Quarterly Review of Economics and Finance, 35/2 (summer): 207-223.

Sargent, T.J. and N. Wallace (1975): Rational Expectations, the Optimal Monetary Instrument, and the Optimal Money Supply Rule. Journal of Political Economy 83, 241-254.

Sims, C. (1992) Interpreting the Time Series Facts: The Effects of Monetary Policy Financial Repression and Economic Growth. 
European Economic Review 36(5), 975-1011.

Taylor, J. B. (1995): The Monetary Transmission Mechanism: An Empirical Framework, Journal of Economic Perspective, 914, 11-26. Tobin, J. (1969). A General Equilibrium Approach to Monetary Theory. Journal of Money Credit and Banking No. 1, 15 - 29

Uanguta, E.\& S. Ikhide(2002): Monetary Policy Transmission Mechanism In Namibia, Bank Of Namibia(BON) Working Paper No.2/02 Uchendu, A. O. (1996): "The Transmission of Monetary Policy in Nigeria". Economic and Financial Review, CBN, Vol. 34(2) 606-624. Vetlov, I., (2002), Analysis of the Real Exchange Rate and Competitiveness in Lithuania', In Relationship between Real Exchange Rate and Competitiveness in the Baltics, Working Papers of Eesti Pank, No. 6, Eesti Pank, Tallinn, pp. 69-100 